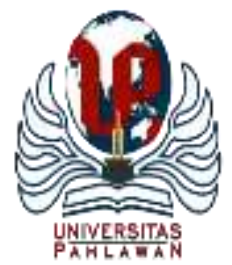

Edukatif : Jurnal Ilmu Pendidikan Volume 3 Nomor 6 Tahun 2021 Halm 4929 - 4943

EDUKATIF: JURNAL ILMU PENDIDIKAN

Research \& Learning in Education

https://edukatif.org/index.php/edukatif/index

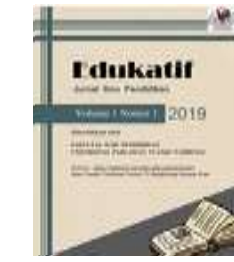

\title{
Pengembangan Four-Tier Test Berbasis Quizizz untuk Mengidentifikasi Konsepsi Gerak Harmonik Sederhana di Sekolah Menengah Atas
}

\author{
Riska Yayang Fitri Ramadani ${ }^{1 凶}$, Haratua Tiur Maria $^{2}$, Hamdani $^{3}$ \\ Universitas Tanjungpura, Indonesia, Indonesia ${ }^{1,2,3}$ \\ E-mail : riskayayangbee@ student.untan.ac.id ${ }^{1}$, haratua.tiur.maria@fkip.untan.ac.id², \\ hamdani@fkip.untan.ac.id ${ }^{3}$
}

\begin{abstract}
Abstrak
Penelitian ini bertujuan untuk mengidentifikasi konsepsi peserta didik pada materi gerak harmonik sederhana berbasis web gamifikasi Quizizz menggunakan tes diagnostik four-tier. Penelitian ini merupakan penelitian pengembangan. Penelitian ini dilaksanakan di SMA Negeri 7 Pontianak. Sampel dalam penelitian ini berjumlah 35 orang peserta didik. Teknik pengumpulan data dilakukan dengan pemberian tes diagnostik four-tier berbasis Quizizz pada peserta didik kelas X MIPA 5. Analisis data penelitian ini dilakukan dengan langkah reduksi data, penyajian data, dan penarikan kesimpulan. Sebelum melakuka penelitian dilakukan validasi terhadap soal tes diagnotik, validasi dilakukan oleh tiga orang validator dengan hasil akhir dari validasi instrumen tes dengan rata-rata dari 3 aspek adalah 88,67\% dengan kriteria "sangat baik" oleh validator sehingga dapat digunakan untuk dilakukan uji tes konsepsi peserta didik. Hasil penelitian ini menunjukkan bahwa peserta didik yang berkategori paham konsep sebesar $14,14 \%$, presentase peserta didik yang berkategori tidak paham konsep sebesar $23,43 \%$, presentase peserta didik yang berkategori miskonsepsi sebesar $51,86 \%$, dan presentase peserta didik yang berkategori eror sebesar 10,57\%.
\end{abstract}

Kata kunci: Identifikasi Konsepsi, Four Tier Diagnostic Test berbasis Quizizz, Gerak Harmonik Sederhana.

\begin{abstract}
This study aims to identify students' conceptions of simple harmonic motion material based on the Quizizz gamification web using a four-tier diagnostic test. This research is a development research. This research was conducted at SMA Negeri 7 Pontianak. The sample in this study amounted to 35 students. Data collection techniques were carried out by administering a four-tier diagnostic test based on Quizizz to students of class $X$ MIPA 5. The data analysis of this study was carried out by means of data reduction, data presentation, and conclusion drawing. Before conducting the research, validation of the diagnostic test questions was carried out, validation was carried out by three validators with the final result of the validation of the test instrument with an average of 3 aspects was $88.67 \%$ with the criteria of "very good" by the validator so that it could be used to test the test students' conceptions. The results of this study indicate that students who are categorized as understanding concepts are $14.14 \%$, the percentage of students who are categorized as not understanding concepts is $23.43 \%$, the percentage of students who are categorized as misconceptions is $51.86 \%$, and the percentage of students who are categorized as errors. by $10.57 \%$.
\end{abstract}

Keywords: Identification of Conception, Four Tier Diagnostic Test using by Quizizz, Simple Harmonnic Motion.

Copyright (c) 2021 Riska Yayang Fitri Ramadani, Haratua Tiur Maria, Hamdani

$\triangle$ Corresponding author

Email : riskayayangbee@student.untan.ac.id

DOI : https://doi.org/10.31004/edukatif.v3i6.1453

ISSN 2656-8063 (Media Cetak)

ISSN 2656-8071 (Media Online) 
4930 Pengembangan Four-Tier Test Berbasis Quizizz untuk Mengidentifikasi Konsepsi Gerak Harmonik Sederhana di Sekolah Menengah Atas - Riska Yayang Fitri Ramadani, Haratua Tiur Maria, Hamdani DOI: https://doi.org/10.31004/edukatif.v3i6.1453

\section{PENDAHULUAN}

Permasalahan pendidikan yang mendasar sering berkaitan dengan penanaman pemahaman konsep yang kadang-kadang keliru. Kurangnya penguasaan konsep oleh peserta didik secara konsisten akan mempengaruhi efektivitas proses belajar selanjutnya. Setelah pembelajaran di sekolah, ternyata seringkali kerangka konsep yang telah dibangun oleh peserta didik menyimpang dari konsep yang benar.

Peserta didik yang menyimpang dari konsep berarti peserta didik tersebut tidak menguasai konsep atau salah konsep. Agar dapat membantu peserta didik secara tepat perlu diketahui terlebih dahulu apakah kesulitan atau masalah yang dihadapi peserta didik tersebut, baru kemudian dianalisis dan dirumuskan pemecahannya (Zaleha, 2017).

Konsepsi peserta didik yang kurang baik salah satunya dapat disebabkan oleh adanya miskonsepsi. Miskonsepsi merupakan pengertian yang tidak akurat tentang konsep, penggunaan konsep yang salah, klasifikasi contoh-contoh yang salah tentang penerapan konsep, pemaknaan konsep yang berbeda, kekacauan konsep-konsep yang berbeda, dan hubungan hierarkis konsep-konsep yang tidak benar (Rahmawati, 2019).

Salah satu tes untuk diagnosis miskonsepsi yaitu Four-tier test. Four-tier test merupakan pengembangan dari three tier test yang dipadukan dengan confidence rating pada alasan jawaban, sehingga lebih akurat tingkat keyakinan atas jawaban dan alasan jawaban (Ismail, 2015). Berbeda dengan Three-tier test yang hanya memiliki satu tingkat keyakinan yang dalam hal ini tingkat keyakinan untuk pengetahuan dan alasan digabung menjadi satu. Four tier-test lebih spesifik dalam mengelompokkan kategori paham konsep, tidak paham konsep, miskonsepsi, dan eror.

Di era yang serba modern ini, tes tidak hanya dilakukan melalui kertas yang diberikan secara langsung kepada peserta didik. Tes berbasis website ini akan lebih memudahkan penelitian terutama disituasi pandemi. Salah satu website yang digunakan sebagai tes online kepada peserta didik adalah Quizizz. Quizizz merupakan sebuah web tool untuk membuat permainan kuis interaktif untuk digunakan dalam pembelajaran di kelas dan dapat digunakan secara online oleh guru dan peserta didik (Nugroho, 2019). Penggunaannya sangat mudah dan memiliki berbagai variasi bentuk soal, bisa memuat gambar dan audio di soal serta memiliki latar yang menarik dan berbagai fitur interaktif lainnya. Quizizz juga dapat mencetak hasil tes dengan mudah dalam bentuk Microsoft Excel.

Berdasarkan hasil pra riset di kelas XI MIA SMA Negeri 7 Pontianak ditemukan hasil ulangan harian materi getaran harmonik di bawah kriteria ketuntasan minimum (KKM), yaitu 75. Sebanyak 21, $6 \%$ dari total peserta didik program jurusan IPA tahun ajaran 2015/2016 yang tuntas dalam belajar (Khairunnisa, 2018). Ketidaktuntasan hasil belajar pada materi gerak harmonik sederhana masih terus terjadi pada tahun ajaran 2019/2020. Berdasarkan hasil pra riset dari 34 peserta didik kelas X MIPA 1 yang tuntas pada penilaian akhir semester (PAS) berjumlah enam orang, 28 orang mengalami ketidaktuntasan pada materi gerak harmonik sederhana. Ketidaktuntasan ini menandakan bahwa peserta didik mengalami kesulitan dalam memahami konsep pada materi getaran harmonik akibatnya peserta didik memiliki konsep yang salah.

Adapun rumusan masalah dalam penelitian ini, yaitu: (1) apakah tes diagnostik four-tier berbasis Quizizz pada materi gerak harmonik sederhana layak digunakan menurut validasi ahli?; (2) apakah tes diagnostik four-tier dapat mengidentifikasi konsepsi peserta didik pada materi gerak harmonik sederhana? Penelitian ini bertujuan untuk (1) mengembangkan tes diagnostik four-tier menggunakan Quizizz pada materi gerak harmonik sederhana.; (2) mengidentifikasi konsepsi peserta didik pada materi gerak harmonik sederhana menggunakan tes diagnostik four-tier berbasis Quizizz. 
4931 Pengembangan Four-Tier Test Berbasis Quizizz untuk Mengidentifikasi Konsepsi Gerak Harmonik Sederhana di Sekolah Menengah Atas - Riska Yayang Fitri Ramadani, Haratua Tiur Maria, Hamdani DOI: https://doi.org/10.31004/edukatif.v3i6.1453

\section{METODE PENELITIAN}

Pendekatan dan metode penelitian ini adalah penelitian dan pengembangan (R\&D) yang bertujuan untuk mengembangkan tes diagnostik four-tier menggunakan web gamifikasi Quizizz. Pelaksanaan penelitian mengikuti prosedur yang dikembangkan oleh Tessmer yang meliputi self evaluation, prototyping, serta field test (Tessmer, 1993). Adapun alur desain formative evaluation sebagai berikut: (1) Tahap Preliminary yaitu menentukan tempat, subjek penelitian, mengatur jadwal dan prosedur penelitian; (2) Tahap Formative Evaluation yaitu (a) analisis dan desain (self evaluation); (b) pembuatan produk (prototyping); (c) validasi pakar (expert review); (d) satu per satu (one-to-one); (e) kelompok kecil (small group); (3) Tes Lapangan (field test) yaitu merevisi desain prototipe kedua dan melakukan uji lapangan. Adapun dalam penelitian ini hanya akan dilakukan sampai tahap formative evaluation dengan uji coba prototipe pada kelompok kecil (Small Group).

Populasi dalam penelitian ini adalah seluruh peserta didik kelas X MIPA SMA Negeri 7 Pontianak semester genap tahun ajaran 2020/2021. Sampel dalam penelitian ini adalah peserta didik kelas X MIPA 5 SMA Negeri 7 Pontianak semester genap tahun ajaran 2020/2021 yang berjumlah 35 orang.

Teknik pengumpulan data yang digunakan dalam penelitian ini adalah tes diagnostik empat tingkat pilihan ganda dengan alasan tertutup yang telah divalidasi oleh 2 orang dosen pendidikan fisika FKIP UNTAN dan 1 orang guru Fisika SMA Negeri 7 Pontianak, lembar validasi dan lembar angket peserta didik. Alat pengumpulan data yang digunakan dalam penelitian ini adalah 20 soal four tier diagnostic test berbasis Quizizz pada materi gerak harmonik sederhana, lembar validasi, dan lembar angket peserta didik.

Sebelum tes diagnostik diberikan kepada peserta didik, dilakukan validasi terlebih dahulu. Butir soal yang telah divalidasi oleh validator maka akan dianalisis. Validator akan diberikan lembar validasi soal dan mengisi dengan skala likert rentang 1 sampai 4. Hasil validasi dari para validator akan dihitung menggunakan formula Aiken (Aiken, 1980), yaitu:

$$
\begin{gathered}
\mathrm{V}=\Sigma \mathrm{s} /[\mathrm{n}(\mathrm{c}-1)] \\
\mathrm{S}=\mathrm{r}-\mathrm{lo}
\end{gathered}
$$

Keterangan :

lo: Angka penilaian validitas terendah.

c : Angka penilaian validitas tertinggi.

$\mathrm{r}$ : Angka yang dberikan oleh penilai.

$\mathrm{n}$ : Jumlah penilai.

Hasil jawaban peserta didik pada tes diagnostik four-tier akan diklasifikasikan dengan kriteria penilaian tes, untuk paham konsep bernilai 3, miskonsepsi bernilai 2, tidak paham konsep bernilai 1, dan eror bernilai 0 . Kemungkinan jawaban peserta didik tersebut dihitung untuk mengetahui persentase peserta didik pada masing-masing kategori memahami, tidak memahami, error, dan miskonsepsi dalam setiap konsep.

$$
P=\frac{f}{n} \times 100 \%
$$

Keterangan :

$\mathrm{P}:$ Persentase (\% kelompok).

$\mathrm{f}$ : Frekuensi (jumlah pada setiap kelompok).

$\mathrm{n}$ : Jumlah seluruh peserta didik 
4932 Pengembangan Four-Tier Test Berbasis Quizizz untuk Mengidentifikasi Konsepsi Gerak Harmonik Sederhana di Sekolah Menengah Atas - Riska Yayang Fitri Ramadani, Haratua Tiur Maria, Hamdani DOI: https://doi.org/10.31004/edukatif.v3i6.1453

\section{HASIL DAN PEMBAHASAN PENELITIAN}

a. Tahap Preliminary

Lokasi penelitian bertempat di SMA Negeri 7 Pontianak. Peneliti menghubungi guru mata pelajaran fisika kelas X MIPA 5 untuk melakukan penelitian di kelasnya dan membuat surat izin penelitian. Selanjutnya peneliti mengatur jadwal penelitian dan prosedur kerja sama dengan guru Fisika kelas X MIPA 5.

b. Tahap Formative Evaluation

Peneliti melakukan analisis dan pendesainan kisi-kisi tes diagnostik, setelahnya peneliti membuat soal tes diagnostik yang berjumlah 20 soal. Setelah pembuatan soal, peneliti membuat kunci jawaban beserta pembahasan alasan jawaban soal, kemudian memindahkan soal ke Quizizz dan terakhir membuat petunjuk pengerjaan soal.

Proses pengambilan data dalam penelitian ini, yaitu pertama dilakukan analisis hasil validasi pada prototipe 1. Penilaian yang terdiri dari tiga bagian yaitu aspek materi, konstruksi, dan bahasa, diisi oleh tiga ahli instrumen tes. Data uji validasi pakar instrumen dihitung menggunakan formula Aiken. Berikut ini hasil analisis validasi pakar:

Tabel.1 Data Uji Validasi Pakar

\begin{tabular}{|c|c|c|c|c|c|c|c|c|}
\hline \multirow[t]{2}{*}{ Aspek Penilaian } & \multicolumn{3}{|c|}{ Nilai } & \multicolumn{3}{|c|}{$S=r-10$} & \multirow{2}{*}{$\begin{array}{c}\mathrm{V}= \\
\sum \mathrm{s} / \mathrm{n}(\mathrm{c}-1)\end{array}$} & \multirow[t]{2}{*}{ Kategori } \\
\hline & V1 & $\mathrm{V} 2$ & V3 & V1 & V2 & V3 & & \\
\hline $\begin{array}{l}\text { Butir soal sesuai dengan } \\
\text { indikator soal }\end{array}$ & 3 & 3 & 4 & 2 & 2 & 3 & 0,78 & Tinggi \\
\hline $\begin{array}{l}\text { Hanya ada satu kunci jawaban } \\
\text { atau jawaban yang benar }\end{array}$ & 3 & 3 & 4 & 2 & 2 & 3 & 0,78 & Tinggi \\
\hline Pengecoh soal & 4 & 3 & 4 & 3 & 2 & 3 & 0,89 & Sangat tinggi \\
\hline $\begin{array}{l}\text { Pokok soal tidak mengarah pada } \\
\text { jawaban soal }\end{array}$ & 4 & 3 & 3 & 3 & 2 & 2 & 0,78 & Tinggi \\
\hline $\begin{array}{l}\text { Wacana, gambar, atau grafik } \\
\text { benar-benar berfungsi }\end{array}$ & 4 & 3 & 4 & 3 & 2 & 3 & 0,89 & Sangat tinggi \\
\hline $\begin{array}{l}\text { Menggunakan bahasa yang baik } \\
\text { dan benar }\end{array}$ & 4 & 4 & 4 & 3 & 3 & 3 & 1,00 & Sangat tinggi \\
\hline
\end{tabular}

Berdasarkan hasil validitas pada tabel.1 maka secara umum hasil rata-rata validasi pakar berdasarkan tiga aspek utama adalah sebagai berikut:

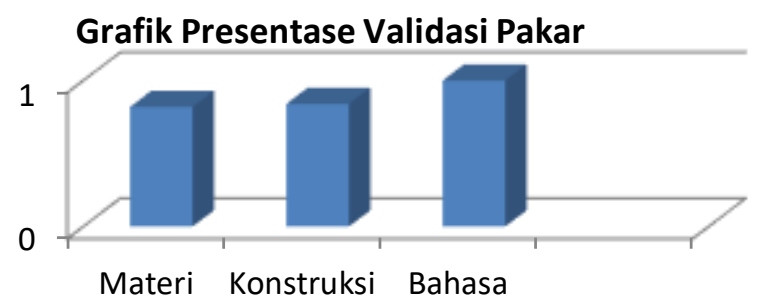

\section{Gambar 1. Grafik presetase validasi pakar berdasarkan 3 aspek, Materi, Konstruksi, dan Bahasa.}

Setelah validasi, tes diagnostik yang telah direvisi yaitu prototipe 2, dilakukan uji coba one-to-one test, untuk mengetahui reliabilitas, tingkat keterbacaan, tingkat kesukaran, dan angket respon peserta didik terhadap tes diagnostik berbasis Quizizz.

Setelah dilakukan uji coba one-to-one test, dihasilkan prototope final yang akan diuji cobakan pada kelompok kecil. Adapun hasil uji coba kelompok kecil dapat dilihat pada tabel berikut: 
Tabel.2 Hasil Identifikasi Tes Diagnostik Peserta Didik

\begin{tabular}{|c|c|c|c|c|}
\hline \multirow[t]{2}{*}{ Peserta Didik } & \multicolumn{4}{|c|}{ Presentase (\%) } \\
\hline & PK & TPK & $\mathrm{M}$ & $\mathrm{E}$ \\
\hline APS & 55,00 & 0 & 45,00 & 0 \\
\hline APA & 5,00 & 0 & 80,00 & 15,00 \\
\hline $\mathrm{AF}$ & 15,00 & 0 & 70,00 & 15,00 \\
\hline $\mathrm{AAA}$ & 20,00 & 0 & 60,00 & 20,00 \\
\hline BAR & 10,00 & 45,00 & 40,00 & 5,00 \\
\hline CYB & 15,00 & 15,00 & 55,00 & 15,00 \\
\hline $\mathrm{EFH}$ & 10,00 & 40,00 & 45,00 & 5,00 \\
\hline FSN & 20,00 & 0 & 60,00 & 20,00 \\
\hline FNA & 0 & 15,00 & 75,00 & 10,00 \\
\hline FAP & 5,00 & 0 & 75,00 & 20,00 \\
\hline IDH & 5,00 & 5,00 & 80,00 & 10,00 \\
\hline $\mathrm{KN}$ & 10,00 & 55,00 & 25,00 & 10,00 \\
\hline MDP & 0 & 100,00 & 0 & 0 \\
\hline MIS & 10,00 & 5,00 & 80,00 & 5,00 \\
\hline MRHP & 5,00 & 35,00 & 50,00 & 10,00 \\
\hline MRA & 10,00 & 0 & 65,00 & 25,00 \\
\hline $\mathrm{MZ}$ & 65,00 & 10,00 & 15,00 & 10,00 \\
\hline NPA & 5,00 & 0 & 80,00 & 15,00 \\
\hline NMPG & 10,00 & 0 & 90,00 & 0 \\
\hline NDD & 5,00 & 15,00 & 75,00 & 5,00 \\
\hline NS & 15,00 & 0 & 65,00 & 20,00 \\
\hline NAK & 10,00 & 75,00 & 15,00 & 0 \\
\hline $\mathrm{NH}$ & 30,00 & 0 & 35,00 & 35,00 \\
\hline $\mathrm{ON}$ & 10,00 & 0 & 85,00 & 5,00 \\
\hline RHHN & 10,00 & 45,00 & 40,00 & 5,00 \\
\hline RSA & 10,00 & 5,00 & 75,00 & 10,00 \\
\hline RRP & 60,00 & 0 & 40,00 & 0 \\
\hline RR & 0 & 60,00 & 20,00 & 20,00 \\
\hline $\mathrm{RS}$ & 10,00 & 75,00 & 15,00 & 0 \\
\hline $\mathrm{RH}$ & 15,00 & 0 & 75,00 & 10,00 \\
\hline SZ & 5,00 & 60,00 & 30,00 & 5,00 \\
\hline SV & 0 & 55,00 & 40,00 & 5,00 \\
\hline SP & 30,00 & 35,00 & 30,00 & 5,00 \\
\hline SRA & 10,00 & 10,00 & 60,00 & 20,00 \\
\hline SF & 0 & 60,00 & 25,00 & 15,00 \\
\hline Total & 495 & 820 & 1815 & 370 \\
\hline Rata-rata & 14,14 & 23,43 & 51,86 & 10,57 \\
\hline
\end{tabular}

Kemudian peneliti juga menganalisis persentase jawaban peserta didik tiap butir soal. Dari hasil yang didapat maka peneliti sajikan dalam bentuk tabel berikut.

Tabel.3 Presentase Peserta Didik per Butir Soal

\begin{tabular}{cccccccccc}
\hline \multirow{2}{*}{ No } & \multicolumn{2}{c}{ PK } & \multicolumn{2}{c}{ TPK } & \multicolumn{2}{c}{ M } & \multicolumn{2}{c}{ E } \\
\cline { 2 - 10 } & $\Sigma$ & $\%$ & $\Sigma$ & $\%$ & $\Sigma$ & $\%$ & $\Sigma$ & $\%$ \\
\hline 1 & 2 & 5,71 & 9 & 25,71 & 21 & 60,00 & 3 & 8,57 \\
\hline
\end{tabular}


4934 Pengembangan Four-Tier Test Berbasis Quizizz untuk Mengidentifikasi Konsepsi Gerak Harmonik Sederhana di Sekolah Menengah Atas - Riska Yayang Fitri Ramadani, Haratua Tiur Maria, Hamdani DOI: https://doi.org/10.31004/edukatif.v3i6.1453

\begin{tabular}{lcccccccc}
\hline 2 & 8 & 22,86 & 7 & 20,00 & 13 & 37,14 & 7 & 20,00 \\
\hline 3 & 4 & 11,43 & 6 & 17,14 & 23 & 65,71 & 2 & 5,71 \\
\hline 4 & 6 & 17,14 & 9 & 25,71 & 15 & 42,86 & 5 & 14,29 \\
\hline 5 & 4 & 11,43 & 11 & 31,43 & 12 & 34,29 & 8 & 22,86 \\
\hline 6 & 2 & 5,71 & 12 & 34,29 & 18 & 51,43 & 2 & 5,71 \\
\hline 7 & 6 & 17,14 & 11 & 31,43 & 18 & 51,43 & 0 & 0 \\
\hline 8 & 5 & 14,29 & 12 & 34,29 & 18 & 51,43 & 0 & 0 \\
\hline 9 & 4 & 11,43 & 10 & 28,57 & 17 & 48,57 & 4 & 11,43 \\
\hline 10 & 7 & 20,00 & 9 & 25,71 & 15 & 42,86 & 4 & 11,43 \\
\hline 11 & 2 & 5,71 & 6 & 17,14 & 24 & 68,57 & 3 & 8,57 \\
\hline 13 & 5 & 14,29 & 7 & 20,00 & 18 & 51,43 & 5 & 14,29 \\
\hline 14 & 2 & 5,71 & 8 & 22,86 & 22 & 62,86 & 3 & 8,57 \\
\hline 15 & 3 & 8,57 & 8 & 22,86 & 23 & 65,71 & 1 & 2,86 \\
\hline 16 & 3 & 8,57 & 8 & 22,86 & 21 & 60,00 & 3 & 8,57 \\
\hline 17 & 5 & 14,29 & 10 & 28,57 & 16 & 45,71 & 4 & 11,43 \\
\hline 18 & 6 & 17,14 & 8 & 22,86 & 17 & 48,57 & 4 & 11,43 \\
\hline 19 & 4 & 11,43 & 8 & 22,86 & 18 & 51,43 & 5 & 14,29 \\
\hline 20 & 2 & 5,71 & 10 & 28,57 & 21 & 60,00 & 2 & 5,71 \\
\hline & 8 & 22,86 & 5 & 14,29 & 11 & 31,43 & 11 & 31,43 \\
\hline
\end{tabular}

Peneliti juga menganalisis profil konsepsi peserta didik dari hasil tes kelompok kecil, profil konsepsi peserta didik dianalisis perbutir soal. Hasil analisis dapat dilihat pada tabel berikut.

Tabel 4. Profil Konsepsi Peserta Didik

\begin{tabular}{|c|c|c|c|}
\hline $\begin{array}{c}\text { Nomor } \\
\text { Soal }\end{array}$ & Konsepsi Peserta Didik & $\Sigma$ & $\%$ \\
\hline \multirow[t]{5}{*}{1} & Simpangan adalah jarak terjauh dari titik seimbang bandul & 13 & 37,1 \\
\hline & Simpangan adalah jarak terdekat dari titik seimbang bandul & 9 & 25,7 \\
\hline & Simpangan adalah jarak terjauh dari titik seimbang dan titik seimbang bandul & 7 & 20,0 \\
\hline & Simpangan adalah jarak terdekat dari titik seimbang dan titik seimbang bandul & & \\
\hline & & 6 & 17,1 \\
\hline \multirow[t]{5}{*}{2} & Amplitudo adalah jarak terjauh dari titik seimbang bandul & 23 & 65,7 \\
\hline & Amplitudo adalah jarak terdekat dari titik seimbang bandul & 4 & 11,4 \\
\hline & Amplitudo adalah jarak terjauh dari titik seimbang dan titik seimbang bandul & 4 & 11,4 \\
\hline & Amplitudo adalah jarak terdekat dari titik seimbang dan titik seimbang bandul & & \\
\hline & & 4 & 11,4 \\
\hline \multirow[t]{4}{*}{3} & Semakin besar massa bandul maka frekuensi akan semakin besar & 9 & 25,7 \\
\hline & Semakin kecil massa bandul maka frekuensi akan semakin besar & 10 & 28,6 \\
\hline & Massa tidak mempengaruhi frekuensi bandul & 11 & 31,4 \\
\hline & Massa bandul berbanding terbalik dengan kuadrat frekuensi bandul & 5 & 14,3 \\
\hline \multirow[t]{4}{*}{4} & Semakin panjang tali bandul maka frekuensi akan semakin besar & 9 & 25,7 \\
\hline & Semakin pendek tali bandul maka frekuensi akan semakin besar & 16 & 45,7 \\
\hline & Panjang tali tidak mempengaruhi frekuensi bandul & 4 & 11,4 \\
\hline & Panjang tali bandul berbanding terbalik dengan kuadrat frekuensi bandul & 6 & 17,1 \\
\hline \multirow[t]{2}{*}{5} & $\begin{array}{l}\text { Banyaknya getaran pada benda berbanding lurus dengan lamanya waktu } \\
\text { untuk satu kali getaran }\end{array}$ & 16 & 45,7 \\
\hline & $\begin{array}{l}\text { Banyaknya getaran pada benda berbanding terbalik dengan lamanya waktu untuk } \\
\text { satu kali getaran }\end{array}$ & 10 & 28,6 \\
\hline
\end{tabular}




\begin{tabular}{|c|c|c|c|}
\hline & Banyaknya getaran tidak mempengaruhi waktu untuk satu kali getaran & 5 & 14,3 \\
\hline & Banyaknya getaran berbanding lurus dengan kuadrat waktu getaran & 4 & 11,4 \\
\hline \multirow[t]{5}{*}{6} & Semakin lama benda bergetar maka frekuensi untuk satu kali getaran semakin kecil & 7 & 20,0 \\
\hline & $\begin{array}{l}\text { Semakin lama benda bergetar maka frekuensi untuk satu kali getaran semakin } \\
\text { besar }\end{array}$ & 14 & 40,0 \\
\hline & Lamanya getaran tidak mempengaruhi frekuensi untuk satu kali getaran & & \\
\hline & Lamanya getaran berbanding lurus dengan kuadrat frekuensi getaran & 8 & 22,9 \\
\hline & & 6 & 17,1 \\
\hline \multirow[t]{4}{*}{7} & Semakin besar amplitudo maka periode semakin kecil & 8 & 22,9 \\
\hline & Semakin besar amplitudo maka periode semakin besar & 14 & 40,0 \\
\hline & Amplitudo tidak mempengaruhi periode & 11 & 31,4 \\
\hline & Amplitude berbanding lurus dengan kuadrat periode & 2 & 5,7 \\
\hline \multirow[t]{4}{*}{8} & Semakin besar amplitudo maka frekuensi semakin kecil & 17 & 48,6 \\
\hline & Semakin besar amplitudo maka frekuensi semakin besar & 7 & 20,0 \\
\hline & Amplitudo tidak mempengaruhi frekuensi & 6 & 17,1 \\
\hline & Amplitude berbanding lurus dengan kuadrat frekuensi & 5 & 14,3 \\
\hline \multirow[t]{4}{*}{9} & Konstanta tidak mempengaruhi frekuensi pegas & 5 & 14,3 \\
\hline & Konstanta berbanding terbalik dengan kuadrat frekuensi pegas & 8 & 22,9 \\
\hline & Semakin kecil konstanta maka frekuensi pegas semakin besar & 12 & 34,3 \\
\hline & Semakin kecil konstanta maka frekuensi pegas semakin kecil & 10 & 28,6 \\
\hline \multirow[t]{4}{*}{10} & Massa tidak mempengaruhi perioda pegas & 7 & 20,0 \\
\hline & Massa berbanding terbalik dengan kuadrat periode pegas & 5 & 14,3 \\
\hline & Semakin kecil massa maka periode pegas semakin besar & 8 & 22,9 \\
\hline & Semakin kecil massa maka periode pegas semakin kecil & 15 & 42,9 \\
\hline \multirow[t]{4}{*}{11} & Kecepatan pada titik A bernilai postif dan kecepatan pada titik B bernilai negatif & 15 & 42,9 \\
\hline & $\begin{array}{l}\text { Kecepatan pada titik A bernilai negatif dan kecepatan pada titik B bernilai positif } \\
\text { Titik A dan titik B merupakan pencerminan dari simpangan maka } \\
\text { kecepatannya sama }\end{array}$ & 6 & 17,1 \\
\hline & Titik B jaraknya dua kali dari titik A sehingga kecepatannya akan berlipat & 10 & 28,6 \\
\hline & & 6 & 17,1 \\
\hline \multirow[t]{4}{*}{12} & Waktu partikel berbanding terbalik dengan besar sudut partikel & 10 & 28,6 \\
\hline & Waktu partikel berbanding lurus dengan besar sudut partikel & 14 & 40,0 \\
\hline & Waktu partikel tidak dipengaruhi oleh besar sudut partikel & 10 & 28,6 \\
\hline & Waktu partikel merupakan kuadrat dari besar sudut partikel & 1 & 2,90 \\
\hline \multirow[t]{4}{*}{13} & Kecepatan bernilai maksimum pada titik seimbang & 7 & 20,0 \\
\hline & Kecepatan bernilai minimum pada titik seimbang & 4 & 11,4 \\
\hline & Kecepatan bernilai 0 pada titik seimbang & 13 & 37,1 \\
\hline & Kecepatan bernilai -1 pada titik seimbang & 11 & 31,4 \\
\hline \multirow[t]{4}{*}{14} & Kecepatan bernilai maksimum pada titik puncak & 18 & 51,4 \\
\hline & Kecepatan bernilai minimum pada titik puncak & 8 & 22,9 \\
\hline & Kecepatan bernilai 0 pada titik puncak & 4 & 11,4 \\
\hline & Kecepatan bernilai -1 pada titik puncak & 5 & 14,3 \\
\hline \multirow[t]{2}{*}{15} & Gaya pemulih pegas berbanding terbalik dengan pertambahan panjang & 12 & 34,3 \\
\hline & Gaya pemulih pegas berbanding lurus dengan pertambahan panjang & 7 & 20,0 \\
\hline
\end{tabular}




\begin{tabular}{clll}
\hline & Gaya pemulih pegas tidak dipengaruhi pertambahan panjang pegas & 11 & 31,4 \\
& Gaya pemulih pegas pertama selalu lebih besar dari pegas yang lainnya & 5 & 14,3 \\
\hline \multirow{2}{*}{16} & Gaya pemulih bernilai 0 pada titik seimbang & 9 & 25,7 \\
& Gaya pemulih bernilai -1 pada titik seimbang & 8 & 22,9 \\
& Gaya pemulih bernilai minimum pada titik seimbang & 7 & 20,0 \\
& Gaya pemulih bernilai maksimum pada titik seimbang & 11 & 31,4 \\
\hline \multirow{2}{*}{17} & Gaya pemulih bernilai maksimum pada titik puncak & 11 & 31,4 \\
& Gaya pemulih bernilai minimum pada titik puncak & 13 & 37,1 \\
& Gaya pemulih bernilai 0 pada titik puncak & 4 & 11,4 \\
& Gaya pemulih bernilai -1 pada titik puncak & 7 & 20,0 \\
\hline \multirow{2}{*}{18} & Massa tidak mempengaruhi energy total pegas & 8 & 22,9 \\
& Massa berbanding terbalik dengan kuadrat energy total pegas & 7 & 20,0 \\
& Semakin kecil massa maka energy total pegas semakin besar & 12 & 34,3 \\
& Semakin kecil massa maka energy total pegas semakin kecil & 8 & 22,9 \\
\hline \multirow{2}{*}{19} & Gaya pemulih tidak mempengaruhi energy total pegas & 9 & 25,7 \\
& Gaya pemulih berbanding terbalik dengan kuadrat energy total pegas & 7 & 20,0 \\
& Semakin kecil gaya pemulih maka energy total pegas semakin besar & 11 & 31,4 \\
& Semakin kecil gaya pemulih maka energy total pegas semakin kecil & 8 & 22,9 \\
\hline \multirow{2}{*}{20} & Simpangan bandul berbanding lurus dengan kecepatan bandul & 20 & 57,1 \\
& Simpangan bandul berbanding terbalik dengan kecepatan bandul & 7 & 20,0 \\
& Simpangan pada bandul tidak mempengaruhi kecepatan bandul & 5 & 14,3 \\
& Simpangan merupakan kuadrat dari kecepatan pada bandul & 3 & 8,6 \\
\hline
\end{tabular}

\section{Pembahasan}

\section{a. Tahap Preliminary}

Langkah awal atau tahap preliminary yang dilakukan dalam penelitian ini adalah menentukan tempat penelitian lalu, peneliti menghubungi guru mata pelajaran fisika setelahnya membuat surat izin pra riset.

b. Tahap Formative Evaluation

Pada tahap ini dilakukan analisis desain, pembuatan produk, validasi, dan uji coba. Berdasarkan hasil tes uji kelompok kecil, dapat diidentifkasi konsepsi dari peserta didik. Peserta didik yang berkategori paham konsep 14,14\%, presentase peserta didik yang berkategori tidak paham konsep 23,43\%, presentase peserta didik yang berkategori miskonsepsi 51,86\%, dan presentase peserta didik yang berkategori eror $10,57 \%$. Hal ini berarti peserta didik belum memahami konsep pada materi gerak harmonik sederhana.

Hasil tes diagnotik four-tier tersebut menunjukkan bahwa instrumen tes dapat digunakan untuk mengidentifikasi konsepsi peserta didik pada materi gerak harmonik sederhana. Sejalan dengan penelitian (Fratiwi, 2017) pengidentifikasian konsepsi dari tes diagnotik two-tier ke tes diagnostik four-tier pada hukum newton menunjukkan hasil bahwa tes diagnostik four-tier akurat untuk mendiagnosis miskonsepsi peserta didik.

Berdasarkan penelitiannya (Fariyani, 2017) menyatakan bahwa salah satu tes yang dapat digunakan guru untuk mengetahui konsepsi peserta didik adalah tes diagnostik. Tes diagnostik akan membantu guru mengetahui miskonsepsi yang dialami peserta didik. Tes diagnostik four tier dapat digunakan sebagai alat untuk mengevaluasi konsepsi peserta didik.

Berdasarkan tabel 3. hasil analisis peserta didik perbutir soal, diketahui peserta didik paling banyak memahami konsep pada soal nomor 2 dan nomor 20, sebesar 22,86\% atau 8 peserta didik. Soal nomor 2 merupakan soal untuk mengidentifikasi amplitudo bandul sedangkan soal nomor 20 berisi soal identifikasi simpangan terhadap frekuensi bandul. 
Dari hasil analisis selanjutnya diketahui peserta didik banyak mengalami tidak paham konsep pada soal nomor 6 dan 8, sebesar 34,29\% atau 12 peserta didik yang tidak paham konsep. Soal nomor 6 merupakan soal untuk mengidentifikasi hubungan banyaknya getaran dengan frekuensi bandul sedangkan soal nomor 8 merupakan soal untuk mengidentifikasi hubungan antara amplitudo dengan frekuensi bandul.

Peserta didik paling banyak mengalami miskonsepsi pada soal nomor 11 , sebesar $68,57 \%$ atau sebanyak 24 peserta didik yang mengalami miskonsepsi. Soal nomor 11 merupakan soal identifikasi kecepatan getar partikel pada tiap titik, yang mengalami miskonsepsi yaitu menjawab kecepatan partikel pada titik A lebih kecil dari kecepatan partikel pada titik B, sedangkan untuk eror peserta didik paling banyak mengalami eror disoal nomor 20 sebesar $31,43 \%$ atau 11 peserta didik. Soal nomor 20 merupakan soal untuk mengidentifikasi hubungan massa dengan simpangan bandul.

Berikut ini hasil validasi dan konsepsi peserta didik pada materi gerak harmonik sederhana.

Tes Diagnostik Four-tier Berbasis Quizizz pada Gerak Harmonik Sederhana Berdasarkan Validasi Ahli

Validasi prototipe 1 dilakukan oleh dua dosen fisika UNTAN dan satu guru mata pelajaran fisika SMA Negeri 7 Pontianak. Adapun hasil akhir dari validasi instrumen tes dengan rata-rata dari 3 aspek adalah $88,67 \%$ dengan kriteria "sangat baik" oleh validator sehingga dapat digunakan untuk dilakukan uji tes konsepsi peserta didik. Instrumen tes dapat digunakan setelah dilakukan revisi, perbaikkan yang dilakukan pada instrumen berdasarkan saran dari validator sebagai berikut.

1. Soal Perbandingan Panjang Tali dan Frekuensi Bandul

Pada soal nomor empat revisi yang dilakukan adalah pada pilihan kunci jawaban yang awalnya periode bandul A lebih kecil dari periode bandul B menjadi periode bandul A lebih besar dari periode bandul B.

2. Soal Pengaruh Frekuensi dan Konstanta Pegas pada Gravitasi.

Pada soal nomor Sembilan revisi yang dilakukan adalah pada indikator dan soalnya. Indikator soalnya berganti menjadi mengidentifikasi hubungan antara frekuensi dan konstanta pada pegas, menyatakan gravitasi tidak berpengaruh pada pegas. Adapun soal setelah revisi sebagai berikut.

Dilakukan percobaan pada pegas yang digetarkan seperti pada gambar dibawah ini!

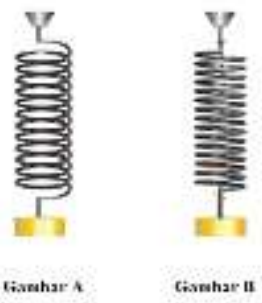

Massa balok pada pegas A sama dengan massa balok pada pegas B, tetapi konstanta pegas A lebih kecil dari konstanta pegas B. Setelah digetarkan pegas akan menghasilkan frekuensi getaran. Bagaimana perbandingan frekuensi kedua pegas tersebut?

A. Frekuensi pegas A sama dengan frekuensi pegas B

B. Frekuensi pegas A dua kali lipatnya frekuensi pegas B

C. Frekuensi pegas A lebih besar dari frekuensi pegas B

D. Frekuensi pegas A lebih kecil dari frekuensi pegas B

\section{Soal Perbandingan Kecepatan Getar pada Grafik Hubungan v-t}

Pada soal nomor 11 revisi yang dilakukan yaitu pada pilihan kunci jawaban. Kunci jawaban awal yang dipilih yaitu kecepatan partikel pada titik A lebih besar dari kecepatan partikel pada titik B, menjadi kecepatan partikel pada titik A sama dengan kecepatan partikel pada titik B.

4. Soal Perbandingan Gaya Pemulih pada Tiga Titik Pegas 
4938 Pengembangan Four-Tier Test Berbasis Quizizz untuk Mengidentifikasi Konsepsi Gerak Harmonik Sederhana di Sekolah Menengah Atas - Riska Yayang Fitri Ramadani, Haratua Tiur Maria, Hamdani DOI: https://doi.org/10.31004/edukatif.v3i6.1453

Pada soal nomor 15 revisi yang dilakukan yaitu pada indikator soal. Indikator soal pada awalnya mengidentifikasi perbandingan gaya pemulih pada tiga titik pegas, menjadi mengidentifikasi perbandingan gaya pemulih pada tiga titik dengan pertambahan panjang yang berbeda pada pegas.

5. Soal Menentukan Nilai Gaya Pemulih pada Titik Seimbang

Pada soal nomor 16 revisi yang dilakukan adalah pada kunci jawaban yang dipilih. Kunci jawaban awal maksimum diubah menjadi minimum.

\section{Tes Diagnostik Four-tier untuk Mengidentifikasi Konsepsi Peserta Didik pada Materi Gerak Harmonik Sederhana}

Setelah dilakukan revisi berdasarkan validasi ahli pada instrumen tes dihasilkan prototipe 2. Prototipe ini digunakan untuk melakukan uji coba pada one-to-one test. Adapun kriteria tes diagnostik (Mahmudah, 2011) sebagai berikut.

1. Tingkat Validitas Soal yang Tinggi

Hasil validasi oleh tiga validator instrumen tes dengan rata-rata dari 3 aspek adalah 88,67\% atau 0.88 dengan kriteria "sangat baik" oleh validator sehingga dapat digunakan untuk dilakukan uji tes konsepsi peserta didik.

2. Tingkat Reliabilitas Soal yang Tinggi

Reliabilitas dari instrumen tes ini dihasilkan untuk r11 hitung sejumlah 0.741. Peneliti dapat menyimpulkan r11 hitung > r11 tabel dengan kriteria reliabilitas tinggi.

3. Tingkat Kesukaran Soal yang Rendah

Tingkat kesukaran instrumen tes dari 20 soal terdapat 5 soal yang berkategori sukar sekali yaitu item soal nomor 4,13,14,15,16. Terdapat 7 soal yang berkategori sukar yaitu item soal nomor 1,2,3,6,10,11,17. Terdapat 4 soal berkategori sedang yaitu item soal nomor 9,18,19,20. Terdapat 3 soal yang berkategori mudah yaitu item soal nomor 7,8,12 dan terdapat satu soal nomor 5 yang berkategori mudah sekali.

4. Item Dikembangkan Berdasarkan Konsepsi Awal Peserta Didik

Indikator soal tes dikembangkan berdasarkan konsepsi awal peserta didik. Terdapat 12 bentuk miskonsepsi dari penelitian terdahulu yang kemudian dikembangkan menjadi instrumen tes diagnostik sebanyak 20 soal.

5. Dirancang Khusus untuk Mendeteksi Kesalahan yang Dialami Peserta Didik

Kesalahan yang dialami peserta didik dapat berbentuk profil miskonsepsi dari materi gerak harmonik sederhana. Berdasarkan tabel 4.11 diperoleh konsepsi peserta didik dari hasil uji coba kelompok kecil menggunakan Quizizz, sebagai berikut.

a. Mengidentifikasi Simpangan dan Amplitudo pada Bandul Sederhana.

Peserta didik yang miskonsepsi menganggap simpangan merupakan jarak terjauh dan merupakan titik seimbang dari bandul itu sendiri, jumlah peserta yang mengalami miskonsepsi yaitu 26 orang atau 74,2 \% . Konsep yang benar adalah simpangan merupakan jarak terdekat dari titik seimbang bandul, yang memiliki konsepsi benar 9 orang atau 25,7\%. Temuan miskonsepsi ini sama dengan temuan miskonsepsi oleh Wulandari, yaitu simpangan adalah jarak terjauh dari suatu getaran (Wulandari, 2015). Peserta didik yang miskonsepsi berjumlah 12 orang atau 34,2 \% menganggap amplitudo merupakan jarak terdekat dan merupakan titik seimbang dari bandul itu sendiri. Konsep yang benar adalah amplitudo merupakan jarak terjauh dari titik seimbang bandul, yang memiliki konsepsi benar berjumlah 23 orang atau 65,7\%.

b. Mengidentifikasi Frekuensi pada Bandul yang Memiliki Massa Berbeda dan Mengidentifikasi Frekuensi pada Bandul yang Memiliki Panjang Tali Berbeda.

Peserta didik yang miskonsepsi berjumlah 24 orang atau 68,6\% menganggap massa mempengaruhi periode bandul. Konsep yang benar yaitu massa tidak mempengaruhi frekuensi bandul, yang mempengaruh 
4939 Pengembangan Four-Tier Test Berbasis Quizizz untuk Mengidentifikasi Konsepsi Gerak Harmonik Sederhana di Sekolah Menengah Atas - Riska Yayang Fitri Ramadani, Haratua Tiur Maria, Hamdani DOI: https://doi.org/10.31004/edukatif.v3i6.1453

frekuensi bandul adalah panjang tali dan gaya gravitasi bumi, yang memiliki konsep yang benar yaitu 11 orang atau $31,4 \%$.

Peserta didik berjumlah 19 orang atau 54,3\% yang mengalami miskonsepsi, menganggap semakin panjang tali bandul maka frekuensi akan semakin besar dan panjang tali bandul tidak mempengaruhi frekuensi dari bandul. Konsep yang benar frekuensi berbanding terbalik dengan panjang tali bandul, yang memiliki konsep yang benar 16 orang atau 45,7\%. Temuan miskonsepsi ini sama dengan temuan Ropandi, yaitu pada sistem ayunan sederhana, perioda dan frekuensi bergantung pada massa bandul (Ropandi, 2017).

c. Mengidentifikasi Hubungan Antara Waktu dan Banyaknya Getaran serta Mengidentifikasi Hubungan

Antara Waktu dan Frekuensi pada Ayunan Bandul.

Peserta didik yang miskonsepsi berjumlah 19 orang atau 44,3\% menganggap banyaknya getaran pada benda berbanding terbalik dengan lamanya waktu untuk satu kali getaran. Konsep yang benar banyaknya getaran pada benda berbanding lurus dengan lamanya waktu untuk satu kali getaran, yang memiliki konsep benar 16 orang atau $45,7 \%$.

Peserta didik yang miskonsepsi berjumlah 27 orang atau 77,1\% menganggap semakin lama benda bergetar maka semakin kecil frekuensi untuk satu kali getaran atau semakin lama benda bergetar maka semakin besar frekuensi untuk satu kali getaran. Konsep yang benar lamanya benda bergetar tidak mempengaruhi frekuensi dari benda, yang memiliki konsep benar 8 orang atau 22,9\%. Temuan miskonsepsi ini sama dengan temuan Rezkizohana yaitu semakin lama benda bergetar, maka waktu yang digunakan untuk satu kali getaran semakin kecil dan frekuensi semakin besar begitu juga sebaliknya (Rezkizohana, 2016).

d. Mengidentifikasi Hubungan Antara Periode dan Amplitudo pada Bandul serta Mengidentifikasi

Hubungan Antara Frekuensi dan Amplitudo pada Bandul.

Peserta didik yang miskonsepsi berjumlah 24 orang atau 68,6\% menganggap semakin besar amplitudo maka periode semakin kecil atau sebaliknya. Konsep yang benar amplitudo tidak mempengaruhi periode, yang memiliki konsep benar 11 orang atau $31,4 \%$.

Peserta didik yang miskonsepsi berjumlah 29 orang atau 81,9\% menganggap semakin besar amplitudo maka frekuensi semakin kecil atau sebaliknya. Konsep yang benar amplitudo tidak mempengaruhi frekuensi bandul, yang memiliki konsep yang benar 6 orang atau 17,1\%. Temuan miskonsepsi ini sama dengan temuan miskonsepsi Ropandi yaitu pada sistem ayunan sederhana, perioda bergantung pada amplitudo (Ropandi, 2017).

e. Mengidentifikasi Hubungan Antara Frekuensi dan Konstanta pada Pegas, Menyatakan Gravitasi Tidak Berpengaruh pada Pegas serta Mengidentifikasi Hubungan Antara Periode dan Massa pada Pegas.

Peserta didik yang miskonsepsi berjumlah 25 orang atau 71,5\% menganggap semakin kecil konstanta maka frekuensi pegas semakin besar dan konstanta tidak mempengaruhi frekuensi pegas. Konsep yang benar semakin kecil konstanta maka frekuensi pegas semakin kecil, yang memiliki konsep benar 10 orang atau $28,5 \%$.

Peserta didik yang miskonsepsi berjumlah 25 orang atau $57,1 \%$ menganggap semakin kecil massa maka periode pegas semakin besar dan massa tidak mempengaruhi periode pegas. Konsepsi yang benar semakin kecil massa maka periode pegas semakin kecil, yang memiliki konsep yang benar 15 orang atau 42,9\%. Temuan miskonsepsi ini sama dengan miskonsepsi yang ditemukan Ropandi yaitu pada sistem beban pada pegas, Perioda bergantung pada percepatan gravitasi (Ropandi, 2017).

f. Mengidentifikasi perbandingan kecepatan getar dan perbandingan waktu partikel pada grafik hubungan vt.

Peserta didik yang miskonsepsi berjumlah 27 atau $75,1 \%$ menganggap bahwa Kecepatan pada titik A bernilai postif dan kecepatan pada titik B bernilai negatif atau sebaliknya, peserta didik juga beranggapan bahwa kecepatan pada titik B bernilai dua kali lipat dari titik A. Konsep yang benar titik A dan B merupakan 
4940 Pengembangan Four-Tier Test Berbasis Quizizz untuk Mengidentifikasi Konsepsi Gerak Harmonik Sederhana di Sekolah Menengah Atas - Riska Yayang Fitri Ramadani, Haratua Tiur Maria, Hamdani DOI: https://doi.org/10.31004/edukatif.v3i6.1453

pencerminan dari simpangan maka nilainya sama, tanda negatif hanya menunjukkan arah dari gerak partikel tersebut, yang memiliki konsep benar 10 orang atau $28,6 \%$.

Peserta didik yang miskonsepsi berumlah 22 orang atau 59,5\% menganggap waktu partikel berbanding terbalik dengan besar sudut partikel dan waktu artikel tidak mempengaruhi sudut partikel. Konsep yang benar waktu partikel berbanding lurus dengan besar sudut partikel, karena semakin lama partikel bergerak maka sudut yang ditempuh semakin besar, yang memiliki konsep benar 14 orang atau 40\%. Temuan miskonsepsi ini sama dengan miskonsepsi yang ditemukan Ropandi yaitu kecepatan tidak bernilai tetap pada setiap titik (Ropandi, 2017).

g. Mengidentifikasi Nilai Kecepatan pada Simpangan Minimum Dan Maksimum.

Peserta didik yang miskonsepsi berjumlah 28 orang atau $80 \%$ menganggap bahwa pada simpangan minimum (titik seimbang) kecepatan bernilai minimum, kecepatan bernilai 0 dan -1 pada titik seimbang. Konsep yang benar pada titik seimbang kecepatan bernilai maksimum, yang memiliki konsep yang benar 7 orang atau $20 \%$.

Peserta didik yang miskonsepsi berjumlah 27 orang atau 77,1\% menganggap bahwa kecepatan bernilai maksimum pada titik puncak, kecepatan bernilai 0 dan -1 pada titik puncak atau titik maksimum. Konsep yang benar kecepatan bernilai minimum pada titik puncak, yang memiliki konsep yang benar 8 orang atau 22,9\%. Temuan miskonsepsi ini sama dengan miskonsepsi yang ditemukan Ropandi yaitu kecepatan bernilai maksimum pada simpangan maksimum (Ropandi, 2017).

h. Mengidentifikasi Perbandingan Gaya Pemulih pada Tiga Titik Pegas

Peserta didik yang miskonsepsi berjumlah 27 orang atau $80 \%$ menganggap bahwa gaya pemulih pegas berbanding terbalik dengan pertambahan panjang dan gaya pemulih pegas tidak dipengaruhi pertambahan panjang pegas. Konsep yang benar gaya pemulih pegas berbanding lurus dengan pertambahan panjang pegas, yang memiliki konsep benar 7 orang atau 20\%. Temuan miskonsepsi ini sama dengan miskonsepsi yang ditemukan Ropandi yaitu gaya pemulih bernilai tetap pada setiap titik (Ropandi, 2017).

i. Mengidentifikasi nilai gaya pemulih pada titik seimbang dan titik maksimum.

Peserta didik yang miskonsepsi berjumlah 24 orang atau 68,6\% menganggap gaya pemulih bernilai minimum pada titik seimbang, gaya pemulih bernilai 0 dan -1 pada titik seimbang. Konsep yang benar gaya pemulih bernilai maksimum pada titik seimbang, yang memiliki konsep yang benar 11 orang atau 31,4\%.

Peserta didik yang miskonsepsi berjumlah 24 orang atau $68,6 \%$ menganggap bahwa gaya pemulih bernilai minimum pada titik puncak, gaya pemulih bernilai 0 dan -1 pada titik puncak. Konsep yang benar gaya pemulih bernilai maksimum pada titik puncak, yang memiliki konsep yang benar 11 orang atau 31,4\%. Temuan miskonsepsi ini sama dengan miskonsepsi yang ditemukan Ropandi yaitu gaya pemulih bernilai minimum pada titik seimbang (Ropandi, 2017).

j. Mengidentifikasi Hubungan Total Energi dengan Massa

Peserta didik yang miskonsepsi berjumlah 23 orang atau 65,8\% menganggap bahwa semakin kecil massa maka energi total pegas semakin kecil dan massa tidak mempengaruhi energi total pegas. Konsep yang benar semakin kecil massa maka energi total pegas semakin besar, yang memiliki konsep yang benar 12 orang atau $34,3 \%$. Temuan miskonsepsi ini sama dengan miskonsepsi yang ditemukan Ropandi yaitu Total energi tidak bergantung pada massa (Ropandi, 2017).

k. Mengidentifikasi Hubungan Total Energi Dengan Gaya Pemulih

Peserta didik yang miskonsepi berjumlah 27 orang atau 77,1\% menganggap bahwa semakin kecil gaya pemulih maka energi total pegas semakin besar dan gaya pemulih tidak mempengaruhi energi total pegas. Konsep yang benar semakin kecil gaya pemulih maka energi total pegas semakin kecil, yang memiliki konsep yang benar 8 orang atau 22,9\%. Temuan miskonsepsi ini sama dengan miskonsepsi yang ditemukan Ropandi yaitu total energi tidak bergantung pada massa (Ropandi, 2017).

1. Mengidentifikasi Pengaruh Simpangan terhadap Kecepatan Bandul 
4941 Pengembangan Four-Tier Test Berbasis Quizizz untuk Mengidentifikasi Konsepsi Gerak Harmonik Sederhana di Sekolah Menengah Atas - Riska Yayang Fitri Ramadani, Haratua Tiur Maria, Hamdani DOI: https://doi.org/10.31004/edukatif.v3i6.1453

Peserta didik yang miskonsepi berjumlah 15 orang atau 42,9\% menganggap bahwa simpangan bandul berbanding terbalik dengan kecepatan bandul dan simpangan tidak mempengaruhi kecepatan bandul. Konsep yang benar simpangan pada bandul berbanding lurus dengan keceptan pada bandul, semakin besar simpangannya maka kecepatan bandul semakin besar, yang memiliki konsep yang benar 20 orang atau 57,1\%. Temuan miskonsepsi ini sama dengan miskonsepsi yang ditemui Boonpo yaitu besar sudut akan mempercepat gerak bandul atau memperlambat gerak bandul (Boonpo, 2015).

6. Bahasa yang digunakan sederhana dan jelas dengan tingkat keterbacaan $\leq 6$

Nilai rata-rata redability index yang diperoleh sebesar 4,37. Berdasarkan kriteria hasil penelitian (Sutrisno, 1999), apabila RI kurang dari enam ( $\mathrm{RI} \leq 6)$ maka soal tes cocok diberikan kepada peserta didik dari jenjang SMA

Instrumen tes yang telah memenuhi kriteria tes diagnostik dapat digunakan sebagai alat untuk mengidentifikasi konsepsi peserta didik. Banyaknya konsepsi yang masih keliru dari peserta didik kelas $\mathrm{X}$ MIPA 5 SMA Negeri 7 Pontianak, membuktikan pengetahuan awal peserta didik pada materi gerak harmonik sederhana masih mengalami kekeliruan. Pengajar perlu mereduksi disub materi apa saja peserta didik mengalami kekeliruan dan dengan ini diharapkan pengajar dapat mengurangi kekeliruan konsep yang dialami peserta didik setelah melihat hasil tes diagnotik four tier berbasis Quizizz.

\section{KESIMPULAN}

Berdasarkan hasil penelitian mengenai pengembangan four-tier test berbasis Quizizz untuk mengidentifikasi konsepsi gerak harmonik sederhana pada peserta didik kelas X di SMA Negeri 7 Pontianak, maka dapat disimpulkan sebagai berikut:

1. Tes diagnostik four-tier berbasis Quizizz layak digunakan untuk mengidentifikasi konsepsi peserta didik berdasarkan validasi ahli. Penilaian oleh validator dilakukan dengan menggunakan angket validasi yang terdiri dari 3 aspek penilaian, yaitu aspek materi, aspek konstruksi, dan aspek bahasa. Hasil akhir dari validasi instrumen tes dengan rata-rata dari 3 aspek adalah 88,67\% dengan kriteria "sangat baik" oleh validator sehingga dapat digunakan untuk dilakukan uji tes konsepsi peserta didik. Hal ini membuktikan tes diagnotik four-tier berbasis Quizizz layak digunakan untuk mengukur konsepsi peserta didik.

2. Hasil tes diagnostik four-tier menunjukkan konsepsi peserta didik kelas X MIPA 5 SMA Negeri 7 Pontianak, dari 35 peserta didik didapatkan presentasi sebagai berikut. Peserta didik yang berkategori paham konsep sebesar $14,14 \%$, peserta didik yang berkategori tidak paham konsep sebesar 23,43\%, peserta didik yang berkategori miskonsepsi sebesar 51,86\%, dan peserta didik yang berkategori eror sebesar 10,57\%. Adapun konsepsi peserta didik yang diperoleh pada materi gerak harmonik sederhana sebagai berikut.

a. Simpangan dan Amplitudo Bandul: (1) Simpangan adalah jarak terjauh dari titik seimbang bandul (37,1\%); (2) Simpangan adalah jarak terdekat dari titik seimbang bandul (25,7\%); (3) Simpangan adalah jarak terjauh dari titik seimbang dan titik seimbang bandul (20\%); (4) Simpangan adalah jarak terdekat dari titik seimbang dan titik seimbang bandul (17,1\%); (5) Amplitudo adalah jarak terjauh dari titik seimbang bandul (65,7\%); (6) Amplitudo adalah jarak terdekat dari titik seimbang bandul, jarak terjauh atau terdekat dari titik seimbang dan titik seimbang $(11,4 \%)$.

b. Massa dan Frekuensi Bandul: (1) Semakin besar massa dan panjang tali bandul maka frekuensi akan semakin besar (25,7\%), semakin kecil (28,6\%); (3) Massa tidak mempengaruhi frekuensi bandul (31,4\%); (4) Massa bandul berbanding terbalik dengan kuadrat frekuensi bandul (14,3\%); (5) Semakin pendek tali bandul maka frekuensi akan semakin besar (45,7\%); (6) Panjang tali tidak mempengaruhi frekuensi bandul (11,4\%); (7) Panjang tali bandul berbanding terbalik dengan kuadrat frekuensi bandul $(17,1 \%)$. 
c. Getaran dan Frekuensi Bandul; (1) Banyaknya getaran pada benda berbanding lurus dengan lamanya waktu untuk satu kali getaran $(45,7 \%)$, berbanding terbalik $(28,6 \%)$; (3) Banyaknya getaran tidak mempengaruhi waktu untuk satu kali getaran (14,3\%); (4) Banyaknya getaran berbanding lurus dengan kuadrat waktu getaran (11,4\%); (5) Semakin lama benda bergetar maka frekuensi untuk satu kali getaran semakin kecil (20\%), semakin besar (40\%); (7) Lamanya getaran tidak mempengaruhi frekuensi untuk satu kali getaran (22,9\%); (8) Lamanya getaran berbanding lurus dengan kuadrat frekuensi getaran $(17,1 \%)$.

d. Amplitudo, Periode, dan Frekuensi Bandul : (1) Semakin besar amplitudo maka periode semakin kecil (22,9\%), semakin besar (40\%); (3) Amplitudo tidak mempengaruhi periode (31,4\%); (4) Amplitudo berbanding lurus dengan kuadrat periode (5,7\%); (5) Semakin besar amplitudo maka frekuensi semakin kecil (48,6\%), semakin besar (20\%); (7) Amplitudo tidak mempengaruhi frekuensi $(17,1 \%)$; (8) Amplitudo berbanding lurus dengan kuadrat frekuensi (14,3\%).

e. Konstanta dan Frekuensi Pegas: (1) Konstanta tidak mempengaruhi frekuensi pegas $(14,3 \%)$; (2) Konstanta berbanding terbalik dengan kuadrat frekuensi pegas $(22,9 \%)$; (3) Semakin kecil konstanta maka frekuensi pegas semakin besar (34,3\%), semakin kecil (28,6\%);

f. Massa dan Periode Pegas: (1) Massa tidak mempengaruhi perioda pegas (20\%); (2) Massa berbanding terbalik dengan kuadrat periode pegas $(14,3 \%)$; (3) Semakin kecil massa maka periode pegas semakin besar $(22,9 \%)$ semakin kecil $(42,9 \%)$.

g. Kecepatan dan Waktu pada Partikel: (1) Kecepatan pada titik A bernilai positif dan kecepatan pada titik B bernilai negatif (42,9\%); (2) Kecepatan pada titik A bernilai negatif dan kecepatan pada titik B bernilai positif, titik B jaraknya dua kali titik A kecepatan berlipat (17,1\%); (3) Titik A dan titik B merupakan pencerminan dari simpangan maka kecepatannya sama $(28,6 \%)$; (4) Waktu partikel berbanding terbalik dengan besar sudut partikel, waktu tidak dipengaruhi besar sudut $(28,6 \%)$ berbanding lurus (40\%); (6) Waktu partikel merupakan kuadrat dari besar sudut partikel (2,90\%).

h. Kecepatan Pegas pada Titik Seimbang dan Puncak: (1) Kecepatan bernilai maksimum pada titik seimbang (20\%), minimum (11,4\%); (3) Kecepatan bernilai 0 pada titik seimbang $(37,1 \%)$; (4) Kecepatan bernilai -1 pada titik seimbang $(31,4 \%)$; (5) Kecepatan bernilai maksimum pada titik puncak (51,4\%), minimum (22,9\%); (7) Kecepatan bernilai 0 pada titik puncak $(11,4 \%)$; (8) Kecepatan bernilai -1 pada titik puncak $(14,3 \%)$.

i. Gaya Pemulih dan Pertambahan Panjang: (1) Gaya pemulih pegas berbanding terbalik dengan pertambahan panjang $(34,3 \%)$, berbanding lurus $(31,4 \%)$; (3) panjang (20\%) Gaya pemulih pegas tidak dipengaruhi pertambahan panjang pegas $(31,4 \%)$; (4) Gaya pemulih pegas pertama selalu lebih besar dari pegas yang lainnya (14,3\%).

j. Gaya Pemulih pada Titik Seimbang dan Puncak: (1) Gaya pemulih bernilai 0 pada titik seimbang (25,7\%). (2) Gaya pemulih bernilai -1 pada titik seimbang (22,9\%); (3) Gaya pemulih bernilai minimum pada titik seimbang (20\%), maksimum (31,4\%); (5) Gaya pemulih bernilai minimum pada titik puncak (37,1\%); (6) Gaya pemulih bernilai 0 pada titik puncak $(11,4 \%)$; (7) Gaya pemulih bernilai -1 pada titik puncak (20\%).

k. Massa, Gaya Pemulih, dan Energi Total Pegas: (1) Massa berbanding terbalik dengan kuadrat energi total pegas (20\%); (2) Semakin kecil massa maka energi total pegas semakin besar (34,3\%), semakin kecil (22,9\%); (4) Gaya pemulih tidak mempengaruhi energi total pegas (25,7\%); (5) Gaya pemulih berbanding terbalik dengan kuadrat energi total pegas (20\%); (6) Semakin kecil gaya pemulih maka energi total pegas semakin besar (31,4\%); (7) Semakin kecil gaya pemulih maka energi total pegas semakin kecil $(22,9 \%)$. 
4943 Pengembangan Four-Tier Test Berbasis Quizizz untuk Mengidentifikasi Konsepsi Gerak Harmonik Sederhana di Sekolah Menengah Atas - Riska Yayang Fitri Ramadani, Haratua Tiur Maria, Hamdani DOI: https://doi.org/10.31004/edukatif.v3i6.1453

1. Simpangan dan Kecepatan Bandul: (1) Simpangan bandul berbanding lurus dengan kecepatan bandul $(57,1 \%)$, berbanding terbalik $(20 \%)$; (3) Simpangan pada bandul tidak mempengaruhi kecepatan bandul (14,3\%); (4) Simpangan merupakan kuadrat dari kecepatan pada bandul (8,6\%).

\section{DAFTAR PUSTAKA}

Aiken, L. R. (1980). Content Validity And Reliability Of Single Items Or Questionnaires. Educational And Psychological Measurement. Https://Doi.Org/10.1177/001316448004000419

Boonpo, J., Youngdee, W., \& Ruangsuwan, C. (2015). Enhancing Students' Understanding In Simple Harmonic Motion By Using Video Analysis. Siam Physics Congress, Krabi, Thailand: Khon Kaen University, Krabi.

Fariyani, Q., Rusilowati, A., \& Sugianto, S. (2017). Four-Tier Diagnostic Test To Identify Misconceptions In Geometrical Optics. Unnes Science Education Journal.

Fratiwi, N. J., Kaniawati, I., Suhendi, E., Suyana, I., \& Samsudin, A. (2017). The Transformation Of TwoTier Test Into Four-Tier Test On Newton's Laws Concepts. AIP Conference Proceedings. Https://Doi.Org/10.1063/1.4983967

Ismail, I. I., Samsudin, A., Suhendi, E., \& Kaniawati, I. (2015). Diagnostik Miskonsepsi Melalui Listrik Dinamis Four Tier Test. Prosiding Simposium Nasional Inovasi Dan Pembelajaran Sains.

Khairunnisa, Djudin, T., \& Erwina, O. (2018). Mengintegrasikan Remediasi Miskonsepsi Menggunakan Model Conceptual Change Tipe Ecirr Dalam Pembelajaran Getaran Harmonis Scanned By Camscanner. Artikel Penelitian UNTAN.

Mahmudah, D. (2011). Secondary Analysis Tentang Tes Diagnostik Skripsi-Skripsi Mahasiswa Pendidikan Fisika FKIP Untan Tahun 2007-2009 Pada Materi Mekanika. Pontianak: FKIP Untan (Skripsi).

Nugroho, D. Y., Situmorang, K., Tahulending, P. S., Maxmilla, M., \& Rumerung, C. L. (2019). Pemanfaatan Teknologi Dalam Pendidikan: Penggunaan Fitur Gamifikasi Daring Di Ypk Penabur Bandar Lampung. Prosiding PKM-CSR, Vol.02(2655-3570).

Rahmawati, T. D., Wahyuningsih, W., \& Dua Getan, M. A. (2019). Pengaruh Model Pembelajaran Contextual Teaching And Learning Terhadap Hasil Belajar Matematika Siswa. Jinop (Jurnal Inovasi Pembelajaran). Https://Doi.Org/10.22219/Jinop.V5i1.8021

Rezkizohana. (2016). Penerapan Model Pembelajaran Generatif Untuk Meremediasi Miskonsepsi Siswa Pada Materi Getaran Di Smp. Penelitian Pendidikan Fisika.

Ropandi, A. (2017). Pengembangan Instrumen Three-Tier Test Untuk Mengidentifikasi Miskonsepsi Siswa Pada Materi Gerak Harmonik Sederhana. Seminar Nasional Fisika Dan Aplikasinya, 2477-0477.

Tessmer, M. (1993). Planning And Conducting Formative Evaluations: Improving The Quality Of Education And Training. In Planning And Conducting Formative Evaluations.

Wulandari, N. A., Djudin, T., \& Oktavianty, E. (2015). Remidiasi Miskonsepsi Siswa Menggunakan Model TGT Berbantuan Kartu Soal Pada Materi Getaran Di SMP. Jurnal Pendidikan Dan Pembelajaran $(J I P P)$.

Zaleha, Z., Samsudin, A., \& Nugraha, M. G. (2017). Pengembangan Instrumen Tes Diagnostik VCCI Bentuk Four-Tier Test Pada Konsep Getaran. Jurnal Pendidikan Fisika Dan Keilmuan (JPFK). Https://Doi.Org/10.25273/Jpfk.V3i1.980 